\title{
S)
}

ISSN 2278 - 0211 (Online)

\section{Influence of the Work Environment on Job Satisfaction among Public Secondary School Teachers in Nakuru West Sub County, Kenya}

\begin{tabular}{c}
\hline Maldrine Tallam \\
Teacher, Department of Science, Afraha High School, Kenya \\
Henry K. Kiplangat \\
Professor, Department of Education, Kabarak University, Kenya \\
Dr. Betty Tikoko \\
Lecturer, Department of Education, Kabarak University, Kenya \\
\hline
\end{tabular}

\begin{abstract}
:
Job satisfaction among public secondary school teachers plays a key role in how they perform their functions. The study sought to determine the influence of work environment on job satisfaction among public secondary school teachers. The study was guided by Herzberg's Two-Factor Theory. The study adopted a descriptive survey research design and carried out in Nakuru West Sub County, Nakuru County, Kenya. The study targeted 326 teachers from 9 public secondary school teachers in Nakuru West Sub County. A sample size of 150 respondents obtained using stratified random sampling was used for the study. Data for the study collected using structured questionnaires. The validity and reliability of data collection instruments was ascertained through content validity and internal consistency respectively. The findings revealed that work environment $(\beta=0.505 ; p \leq 0.05)$ significantly influence satisfaction among public secondary school teachers in Nakuru West Sub County, Kenya. Based on the results of the study, it can be concluded that work environment significantly influenced satisfaction among public secondary school teachers in Nakuru West Sub County, Kenya. The positive and moderate relationship between the work environment and job satisfaction observed implied that improving the work environment in the schools would lead to improvements in teachers' job satisfaction. Therefore, the study recommends with respect to policy that the Ministry of Education should make minimum policies on the level of school infrastructure required for public secondary schools and also make provisions for upgrading existing school infrastructure
\end{abstract}

Keywords: Job satisfaction, workload, compensation, work environment

\section{Introduction}

Recent studies on job satisfaction within the teaching profession suggest that there are several factors contributing to either satisfaction among this class of workers but these factors vary contextually, hence, cannot be generalized. For example, Halpert (2011) in a study in the US found that a significant proportion of teachers were still not satisfied with their jobs and this was attributed to school factors, such as; the volume of non-teaching workload, equitability in the distribution of work, and professional autonomy, were found to influence the job satisfaction of secondary school teachers significantly. In contrast, in the UK, a study by Killworth (2018) revealed that school employees in the UK are more committed to their schools than employees of other non-teaching organizations elsewhere in the economy. However, when the level of satisfaction was compared within the teaching in other Western and European countries, it was established that teachers in Australia, New Zealand, the USA, Bulgaria, Canada (Alberta), Denmark, Israel, the Netherlands, New Zealand, Romania, Sweden, the USA, Brazil, Italy and Norway were much happier with their jobs than those in the UK (Schleicher, 2015).

In South Africa Iwu, Gwija, Benedict and Tengeh (2013) found that working conditions, job security, and perceived growth opportunities were contributing factors to secondary teachers' job satisfaction. Okonkwo and Obineli (2011) in Nigeria argued that inspired workplace will result in inspired workers and draws attention to the importance of work performance, the social relationships, quality, and style of buildings and offices. In Kenya, studies on job satisfaction among secondary school teachers have yielded mixed results making them inconclusive. For example, Omondi (2015) study on job satisfaction among public secondary school teachers in Mombasa County, Kenya established that teachers were satisfied with their overall performance on the job. However, Nzomo's (2016) reported that examination of factors affecting job satisfaction among public secondary school teachers in Machakos County, Kenya revealed that the teachers had low levels of job satisfaction with most teachers. 
Studies on job context factors in Nakuru County have not explicitly linked the problem with secondary teachers' job satisfaction. For example, Mwangi (2012) study in the then Nakuru North District which focused mainly on secondary school teachers' relationship with their principals. It can be deduced from the majority of studies reviewed above that that job satisfaction among secondary school teachers was still a challenge in several contexts globally. However, it is also evident from the studies that job context factors affecting teacher job satisfaction vary from context to context and, therefore, are not necessarily generalizable. It can be deduced from the majority of studies reviewed above that that job satisfaction among secondary school teachers was still a challenge in several contexts globally. However, it is also evident from the studies that job context factors affecting teacher job satisfaction vary from context to context and, therefore, are not necessarily generalizable.

\subsection{Statement of the Problem}

One of the most important issues dealt with in today's schools is how to increase the quality of education and teachers' job satisfaction plays a very important role in this regard (Ghavifekr \& Pillai, 2016). Teachers job satisfaction reflect on their students and, therefore, efforts should be undertaken to ensure they derive maximum satisfaction with their occupations. However, in Kenya, despite significant redress of issues affecting teachers job satisfaction by multiple stakeholders, most teachers are unsettled in their work-stations while others are contemplating quitting the profession altogether for other promising careers. If the performance and teacher job change trends are taken into consideration, it would suggest that there is a deep-rooted systemic problem in the profession affecting job satisfaction among secondary school teachers (Ogonda, Orwa, Wambua \& Muli, 2015). This is already reflecting on their performance in areas where teachers are least satisfied such as in Nakuru West Sub County.

Further, going by the levels of teacher job change in the area, where a good number - a cumulative average of $16 \%$ between 2015 and 2018 - of teachers have been lost to other professions with majority 11.2\% going to the County Governments (Nakuru County Education Office, 2019), it would lead to the conclusion that a growing number of teachers in the area are not satisfied with the teaching profession and career experiences as a whole. So far, studies done in Nakuru County (for example, Mwangi, 2012; Kamunjeru et al., 2012) have not explicitly linked job contextual factors with secondary teachers' job satisfaction. Moreover, the uniqueness of job contextual factors makes it difficult to generalize the outcome of other similar studies to the area, since job satisfaction is not always caused by the same factors. This study, therefore, sought to investigate the influence of job context factors on job satisfaction among teachers in public secondary schools in Nakuru West Sub-County.

\subsection{Objective of the Study}

To establish the influence of the work environment on job satisfaction among public secondary school teachers in Nakuru West Sub County, Kenya.

\section{Literature Review}

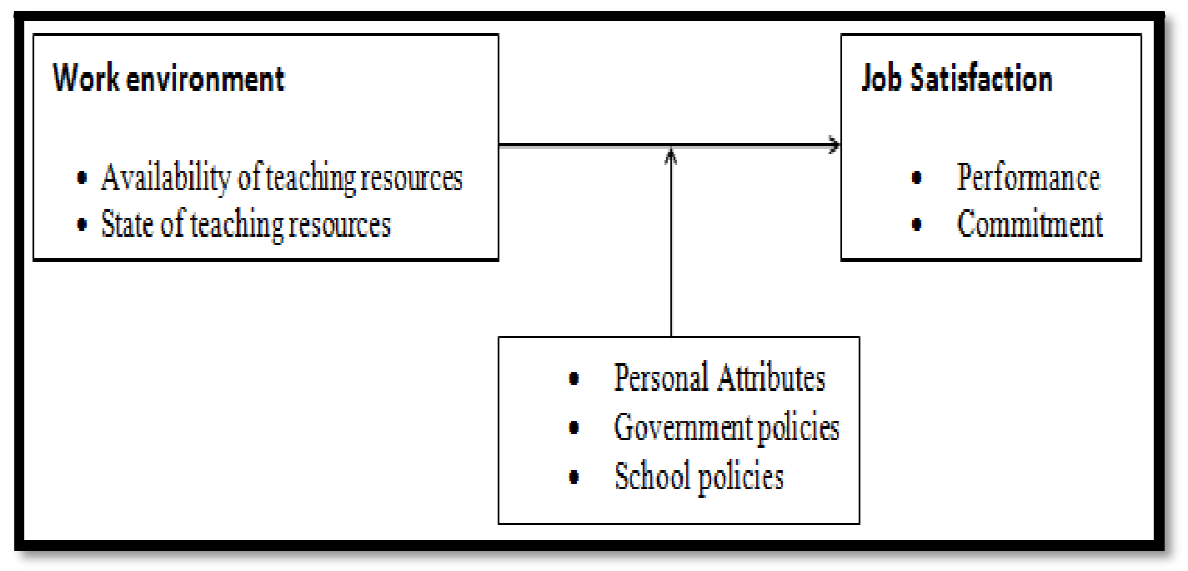

Figure 1: Conceptual Framework

\section{Research Design}

This study adopted a descriptive survey research design. According to Kombo and Tromp (2006) the major purpose of descriptive research is to describe the state of affairs as it exists. The design was useful in obtaining both qualitative and quantitative data. The design was also useful when collecting information about people's attitudes, opinions, habits or any of the variety of education or social issues.

\subsection{Target Population}

The target population in academic research refers to an entire group of individuals, events or objects having common observable characteristics. According to Mugenda and Mugenda (2013), a target population is a population to which a researcher wants to generalize his or her results. The study targets 326 teachers in all the 9 public secondary schools in Nakuru West Sub County. 


\subsection{Sampling Frame}

\subsubsection{Sample Size and Sampling Technique}

The total population of teachers under consideration in public schools is 326 , which is a large enough population to warrant random sampling. The sample size for the teachers was computed using the formula proposed by Nassiuma (2000) as

follows;

$$
n=\frac{N c^{2}}{c^{2}+(N-1) e^{2}}
$$

Where $\mathrm{n}=$ sample size, $\mathrm{N}=$ population size, $\mathrm{c}=$ coefficient of variation $(\leq 30 \%)$, and $\mathrm{e}=$ error $\operatorname{margin}(\leq 5 \%)$. In this study $\mathrm{c}$ is taken as $50 \%$ as reccommended by Nassiuma (2000), e to be $2 \%$ and $\mathrm{N}=535$, therefore, fitting this into the formula:

$$
n=\frac{326 *(0.5)^{2}}{(0.5)^{2}+(326-1) *(0.03)^{2}}=150.23 \approx 150
$$

A sample size of 150 teachers obtains from the above formula. Since the number of teachers is high, systematic random sampling was used to select teachers for the study. The use of both sampling methods was intended to make the sample representative enough of the entire population under study while also introducing the element of randomness.

\subsection{Instrumentation}

In this study, the researcher made use of the questionnaire to collect primary data and from both the teachers and principals. Questionnaire method is the most commonly used in survey studies and was preferred in this study because it is an efficient way of generating large amounts of data, of reaching a wide population and is also easy to administer.

\section{Results}

\subsection{Percentages and Mean Statistics on Perception of the Work Environment}

Questionnaire items on the work environment were selected and their percentage scores computed and the means and standard deviations determined. This provided the basic trends of the data from which the reactions could be analysed. The findings are presented in Table 1.

\begin{tabular}{|c|c|c|c|c|c|c|}
\hline Statement & SD(\%) & D(\%) & A(\%) & SA(\%) & Mean & St.d Dev \\
\hline The class room have chairs for teachers & 15.5 & 53.6 & 26.4 & 4.5 & 2.2 & 0.752 \\
\hline The classroom has tables for teachers & 3.6 & 87.3 & 7.3 & 1.8 & 2.07 & 0.422 \\
\hline The classroom is well ventilated & 1.8 & 63.6 & 30.9 & 3.6 & 2.36 & 0.586 \\
\hline There is adequate lighting & 7.3 & 58.2 & 31.8 & 2.7 & 2.3 & 0.643 \\
\hline Classrooms are overcrowded & 1.8 & 15.5 & 75.5 & 7.3 & 1.41 & 0.849 \\
\hline Teachers have ample office space & 2.7 & 3.6 & 40 & 53.6 & 1.7 & 0.698 \\
\hline We have adequate toilet facilities in our school & 7.3 & 87.3 & 3.6 & 1.8 & 2 & 0.428 \\
\hline We have safe drinking water for teachers & 8.2 & 83.6 & 7.3 & 1 & 2.01 & 0.439 \\
\hline The school provides meals for teachers & 7.3 & 61.8 & 26.4 & 4.5 & 2.28 & 0.665 \\
\hline $\begin{array}{c}\text { There is adequate internet connectivity for } \\
\text { teachers }\end{array}$ & 84.5 & 7.3 & 5.5 & 2.7 & 1.26 & 0.686 \\
\hline $\begin{array}{c}\text { There are adequate reference materials for } \\
\text { teachers }\end{array}$ & 65.5 & 27.3 & 5.5 & 1.8 & 1.44 & 0.684 \\
\hline $\begin{array}{c}\text { Aggregate } \\
\quad\end{array}$ & & & & 1.912 & 0.623 \\
\hline
\end{tabular}

Table 1: Work Environment on Job Satisfaction

The results in Table 1 indicate that the classrooms did not have chairs for teachers as indicated by majority $53.6 \%$ ) who disagreed. Majority (87.3\%) of the respondents also disagreed that their classroom had tables for teachers. This shows that the schools were under-furnished for teaching and learning and could be a reason behind the lack of job satisfaction among the teachers. Indeed, the findings agree with Ntumi (2016) who found that teaching and learning in schools are hampered by lack of tables and chairs in the classrooms and this was a cause of lack of job satisfaction.

The findings also indicate that the classrooms were not well ventilated as indicated by most respondents who disagreed (63.6\%). Most schools' classrooms also lacked adequate lighting as indicated by most teachers who disagreed (58.2\%). This was likely to affect the job satisfaction of teachers as ventilating and lighting the classrooms was important to teacher job satisfaction as they are the primary workstations of the teachers. According to a study by Okonkwo and Obineli (2016), conditions such as suitable temperature, humidity, ventilation, lighting, cleanliness of the workplace and adequate tools and equipment are important in job satisfaction. Good working conditions provide greater physical comfort for teachers and boost their morale. While very poor conditions breed frustration and regret and consequently a high 
sense of dissatisfaction. This is because a workplace environment with essential facilities is a prelude to job satisfaction among workers. Environment conditions enhance working.

Most teachers agreed (75.5\%) that their classrooms were overcrowded. The overcrowding of classrooms could necessarily lead to dissatisfaction among teachers as pointed out by Khan and Iqbal (2014) who found in their study that one of the major constraints that affect teacher job satisfaction was overcrowding in classrooms. Further, most programmes of instruction and pupil service require adequate physical facilities including school buildings, grounds, and equipment. Mugambi's (2014) study in Tharaka Nithi County, Kenya had also revealed that the majority of the teachers felt that the classrooms were not attractive and friendly. Most of the classrooms were congested while and did not meet the hygienic threshold befitting the standards required in the secondary school learning environment.

The findings also indicate that the teachers did not have ample office space as indicated by most of the respondents who disagreed (53.6\%). This could affect the level of job satisfaction of the teachers as indicated by Shonje, (2016) who linked low level of job satisfaction among secondary school teachers in Tanzania to among other things a shortage of office space and chairs. Further, most of the teachers also disagreed (87.3\%) that their schools had adequate toilet facilities while $83.6 \%$ also disagreed that their schools had safe drinking water for teachers. Most of the schools in the area also did not provide meals for teachers as indicated by majority $(61.8 \%)$ of the teachers who disagreed. This could also affect their levels of job satisfaction as indicated by kelvin (2016) whose study revealed that provision of free/subsidized meals and refreshments contributed to teacher job satisfaction. Most schools did not have adequate internet connectivity for teachers as indicated by most teachers who disagreed (84.5\%) and also lacked adequate reference materials for teachers (65.5\%). Currently, the internet is a very important teaching and learning resource as it enables both the teacher and learner to access important reference material which is not easy to obtain locally and as such the availability of the internet can enrich learning. Therefore, lack of internet or inadequate supply of internet could potentially lead to loss of job satisfaction among teacher in this digital world. Further, as learning is a continuous process, adequate reference material in hard copy is equally important. Tayyar (2014) observed that teacher satisfaction is affected in lower grades in South African schools due to lack of adequate textbooks. Teachers may be committed to doing their best to teach reading but their efforts may be rendered futile in situations where there is a lack of the most important resources necessary for teaching and learning.

Further, the overall work environment index determined by aggregate mean $(\mathrm{m}=1.912)$ and standard deviation $(S D=.623)$ observed suggests that there was general disagreement with the statements describing the working environments in the schools. These are indications that the configurations of the working environment in the public secondary schools especially in terms of the state of physical infrastructure and teaching and learning material as well as water and sanitation were unsatisfactory. Chimombe (2015) in Zambia had asserted that physical resources enhance the conducive environment that promotes effective teaching and learning while Tayyar (2014) established that inadequate teaching materials and housing were critical dissatisfies among teachers. Situations in which teachers have to perform their professional duties with little or no resources can be very demanding indeed and eventually impact their job satisfaction negatively.

\subsection{Regression of Work Environment on Job Satisfaction among Teachers}

Bivariate regression analysis was conducted to determine whether there was a significant relationship between Work Environment and Job Satisfaction among Teachers. The results were then used to test the corresponding hypothesis stated for the study. The decision rule was to accept the hypotheses if the corresponding $\mathrm{p}$-values was greater than $\mathrm{p}>$ 0.05. The findings are summarized in Table 2.

\begin{tabular}{|c|c|c|c|c|c|}
\hline & \multicolumn{2}{|c|}{ Unstandardized Coefficients } & $\begin{array}{c}\text { Standardized } \\
\text { Coefficients }\end{array}$ & t & Sig. \\
\hline & $\mathrm{B}$ & Std. Error & Beta & & \\
\hline $\begin{array}{c}\text { (Constant) } \\
\text { Environment }\end{array}$ & 6.375 & 2.568 & & 2.482 & 0.015 \\
\hline R & 0.505 & 0.12 & 0.476 & 4.191 & 0.000 \\
\hline R Square & 0.476 & F & 17.562 & & \\
\hline $\begin{array}{c}\text { Adjusted R } \\
\text { Square }\end{array}$ & 0.227 & df & $(1,107)$ & & \\
\hline
\end{tabular}

Table 2: Regression of Work Environment on Job Satisfaction among Teachers

a. Dependent Variable: Job Satisfaction

b. Predictors: (Constant), Work Environment

Table 2 shows that the model Pearson Product Moment correlation coefficient is $\mathrm{R}=0.476$ and the model adjusted $\mathrm{R}$-square, $\mathrm{R}^{2}$ is 0.206 which suggests that the model with the schools' Work Environment as the independent variable could explain up to $20.6 \%$ of the variations in the dependent variable, that is, job satisfaction among public secondary school teachers in Nakuru West Sub County. The rest of the variations could be explained by the variables not fitted in the model. Moreover, the model's F-statistic is 17.562 with $p=0.000 \leq p=0.05$ with 1,107 degrees of freedom, which further confirms that the explanatory variable, Work Environment, is significant in explaining variations in the dependent variable. In addition, the findings on the model coefficients suggest that Work Environment had a significant, positive and moderate relationship with job satisfaction among public secondary school teachers in Nakuru West Sub County $(\beta=$ 
0.505; $\mathrm{p} \leq$ 0.05). This finding implies that a unit increase in Work Environment will necessarily translate to a +0.505 increase in standard deviations in variations of job satisfaction among public secondary school teachers in Nakuru West Sub County.

These findings are consistent with those of Boyd et al., (2006) as well as Shaw and Newton (2014) in the US which that found that working conditions substantially influence teachers' output and are important predictors of New York City teachers' decisions to change schools or leave the profession. They also agree with Okonkwo and Obineli (2016) who found that many teachers in public schools lack job satisfaction resulting from the poor condition of the environment of their workplace. Okeke and Mtyuda (2017) also found that lack of resources is a cause of dissatisfaction in schools. It is often frustrating for teachers to work without basic resources that are required to ensure effective teaching and learning.

\section{Conclusion}

Based on the results of the study, it can be concluded that work environment significantly influenced satisfaction among public secondary school teachers in Nakuru West Sub County, Kenya. The positive and moderate relationship between the work environment and job satisfaction observed implied that improving the work environment in the schools would lead to improvements in teachers' job satisfaction.

\subsection{Recommendations}

The findings revealed that the state of the schools' work environment was not satisfactory, however, improvements on this could significantly raise the levels of teacher job satisfaction. Therefore, the study recommends with respect to policy that the Ministry of Education should make minimum policies on the level of school infrastructure required for public secondary schools and also make provisions for upgrading existing school infrastructure.

\section{References}

i. Boyd, D., Grossman, P., Lankford, H., Loeb, S., \& Wyckoff, J. (2006). How changes in entry requirements alter the teacher workforce and affect student achievement. Education Finance and Policy, 1(2), 176-216

ii. Chimombe, T. (2015). The factors that affect career choice among high school students in Marondera district. (Unpublished Masters Thesis), Midlands University, Zimbabwe

iii. Ghavifekr, S., \& Pillai, N. S. (2016). The relationship between school's organizational climate and teacher's job satisfaction: Malaysian experience. Asia Pacific Education Review, 17(1), 87-106.

iv. Halpert, M. A. (2011). Factors affecting teacher satisfaction in an Urban School District. Arizona : Arizona State University.

v. Iwu, C. G., Gwija, S. A., Benedict, H. O., \& Tengeh, R. K. (2013). Teacher job satisfaction and learner performance in South Africa. Journal of Economics and Behavioral Studies, 5(1), 2220-6140.

vi. Kamunjeru, N. W., Chepkilot, R., Ochieng, I. E. O., \& Raja, R. S. (2012). Analysis of Factors that Affect Teachers" Motivation in Secondary Schools: A Case of Nakuru Municipality, Rift Valley Province-Kenya. International Journal of Scientific Research, 1(5, Oct 2012)

vii. kelvin. L. (2016). Role of motivation in teacher's job performance in public and private secondary schools in Tabora Municipality. University of Tanzania: Dissertation.

viii. Khan, P., \& Iqbal , M. (2014). Over crowded classroom: A serious problem for teachers. childhood development teachers' motivation in, Kenya. Asian Journal of Teacher Education, 2(3), 46-60.

ix. Kombo, D.S., and Tromp, D.L (2006). Proposal and Thesis Writing. An Introduction. Nairobi: Paulines Publications Africa.

x. Mwangi, J. W. (2012). Effects of leadership styles on teachers' job performance and satisfaction.

xi. Mugambi, M. M. (2014). Teachers' perceptions on how selected school factors affect learning in pre-primary's in Meru South District, Tharaka Nithi County, Kenya. (Unpublished Thesis), University of Nairobi:

xii. Mugenda, A., \& Mugenda, O. (2013). Research methods: quantitative and qualitative approaches. Nairobi: ACTS Press.

xiii. Nakuru County Education Office. (2019). County Integrated Development Plan. Nakuru. Government printer.

xiv. Nassiuma D. K. (2000). Survey sampling: Theory and methods. Njoro, Kenya: Egerton University Press.

xv. Ntumi, S. (2016), Challenges Pre-primary Teachers Face in the Implementation of the Early Childhood Curriculum in the Cape Coast Metropolis. Journal of Education and Practice, 7(1), 55-62.

xvi. Nzomo, M. K. (2016) School factors influencing job satisfaction among teachers in public schools in Machakos East Sub County Sub-County, Kenya. (Unpublished Master's Thesis), University of Nairobi:

xvii. Ogonda, F. O., Orwa, B. H., Peter, W. P., \& Jedida, M. V. (2015). An Analysis of Work Motivation and Teacher Job Satisfaction in Public Secondary Schools in Rarieda Sub-County, Kenya. Journal of Investment and Management, 4(6), 377-390.

xviii. Okeke, C. I., \& Mtyuda, P. N. (2017). Teacher job dissatisfaction: Implications for teacher sustainability and social transformation. Journal of Teacher Education for Sustainability, 19(1), 54-68.

xix. Okonkwo, M.C. \& Obineli S.A. (2011). The Roles of counselling in promoting good leadership: Anambra state on the focus. Review of Behavioural Sciences (JRBS), 3(1), 144-153

xx. Omondi, M.F. (2015). Employee retention and satisfaction in pre-primary schools in Kisumu, Kenya. (Unpublished MEd Thesis), Kenyatta University:

xxi. Shaw, J., \& Newton, J. (2014). Teacher retention and satisfaction with a servant leader as principal. Education, 135(1), 101-106 
xxii. Shonje, G. N. (2016). The Influence of Working Conditions on Teachers' Job Satisfaction: the Case of Kisarawe District Public Secondary School Teachers, Tanzania (Doctoral dissertation), The Open University of Tanzania.

xxiii. Tayyar, K. A. (2014). Job satisfaction and motivation amongst secondary school teachers in Saudi Arabia. (Unpublished PhD Thesis), University of York: 